Sophie CARTWRIGHT*

\title{
EUSTATHIUS OF ANTIOCH IN MODERN RESEARCH
}

Eustathius of Beroea/Antioch remains an elusive figure, though there is a growing recognition of his importance to the history of Christian theology, and particularly the early part of the so-called 'Arian' controversies. The recent publication of a fresh edition of his writings, including a newly-attributed epitome entitled Contra Ariomanitas et de anima, demands fresh consideration of Eustathius ${ }^{1}$. However, the previous scholarship on Eustathius is too little known for such an enterprise to take place. This article has two related tasks: firstly, to provide a comprehensive survey of the treatment of Eustathius in modern scholarship ${ }^{2}$; secondly, to assess the current state of research on Eustathius. With the exception of Eustathian exegesis, the work on Eustathius's theology between the early twentieth century and the publication of the new epitome has been extremely limited. The scholarship that has followed this publication has yet to situate its observations within more recent historiographical developments in patristic theology and philosophy, but points towards several contours that must be fundamental to this endeavour. Firstly, Eustathius's relationship to Origen must be closely considered in connection with his long-noted dependence on Irenaeus and other theologians from Asia Minor. Secondly, Aristotle, or 'Aristotelianism', suggests itself as an important resource for Eustathius - this resource must now be understood in light of recent discussions on the role of Aristotle's thought, and its relation to Platonism, in antiquity. This can, in turn, help to elucidate the history of Irenaeus's legacy, Origenism, and readings of Aristotle in the fourth century.

1. Eustathius's life. The details of Eustathius's life are uncertain, and the chronology of many key events remains controversial. Eustathius became

* Dr Sophie Cartwright is the CertHE [Certificate in Higher Education] Tutor in the Centre for Open Studies Teaching of University of Glasgow; Sophie.Cartwright@glasgow.ac.uk.

${ }^{1}$ Cf. Eustathius Antiochenus, Contra Ariomanitas et de anima, ed. J.H. Declerck: Eustathii Antiocheni, patris Nicaeni, opera quae supersunt omnia, CCG 51, Turnhout 2002, Brepols, 63-130. All references to the fragments are according to Declerck's numbering system (=D).

${ }^{2}$ In view of the fact that the details of research on Eustathius are not widely known, I take a broadly chronological approach, but sometimes it has proved expedient to examine a particular theme holistically, and this occasionally interrupts the chronology. 
bishop of Beroea at some point before the outbreak of the 'Arian' controver$\mathrm{sy}^{3}$. He was translated to the see of Antioch, perhaps at the Synod of Antioch in 324/325, and attended the Council of Nicaea in $325^{4}$. In the years immediately following Nicaea, he wrote extensive anti-subordinationist polemic, and Eusebius of Caesarea was among his key opponents. He was deposed in 327-328, in circumstances relating to Constantine's change of mind in favour of the Eusebian party ${ }^{5}$. Eustathius presumably died in exile, as he made no attempt to return to his see in 337 , though, as we shall see, some scholars place his date of death later.

Only one safely Eustathian work remains in full: Engastrimytho contra Origenem, an exegetical treatise on 1 Samuel 28 (LXX 1 Kingdoms 28), attacking Origen's interpretation of the passage. There are numerous fragments, the majority of them from anti-subordinationist works. Several other works have been attributed to Eustathius in modern scholarship, to which we now turn.

2. A survey of modern scholarship. Several trends are prominent in the treatment of Eustathius in modern research. Firstly, Germanic and Francophone scholarship have generally shown more interest in Eustathius than their Anglophone counterpart. Secondly, a teleological approach to Eustathius is especially pointed, partly due to the fact that he appears more often in a catalogue of significant thinkers than on his own. His Christology is frequently discussed as an important precursor to Nestorianism, and his exegesis as an example of Antiochene 'literalism'. The concept of Eustathius's theology as belonging to a specific tradition associated with Asia Minor and Syria, or more specifically Antioch, and held in contradistinction to an Alexandrian tradition, gained prominence in German Protestant scholarship in the early twentieth century, and recurs in various guises across much of the later research. There has also been a clear recognition that the circumstances surrounding his deposition are key to the contested ecclesiastical and imperial politics of the

${ }^{3}$ On Eustathius's accession to Beroea, see M. Spanneut, Eustathe d'Antioche, DHGE XVI 13-23, spec. 13. Theodoret writes (HE I 3), that Eustathius was bishop of Beroea when Alexander of Alexandria wrote to Alexander of Constantinople, and similarly to many other bishops, about Arius. For Eustathius's accession to Antioch, see R. Burgess, Studies in Eusebian and post-Eusebian chronography, Stuttgart 1999, Franz Steiner, 183-190.

${ }^{4}$ The scholarship surrounding the Council of Antioch 324/5 is complex, and is discussed below.

${ }^{5}$ Discussions on Eustathius's deposition are considered below and can be found in: H. Chadwick, The Fall of Eustathius of Antioch, JTS 49 (1948) 27-35; T.D. Barnes, Emperor and Bishops, A.D. 324-344. Some Problems, „American Journal of Ancient History” 3 (1978) 53-75; R. Hanson, The Fate of Eustathius of Antioch, ZKG 95 (1984) 171-179; idem, The Search for the Christian doctrine of God: the Arian Controversy 318-381, Oxford 1988, Oxford University Press, 210; Burgess, Studies in Eusebian, p. 191-196; idem, The Date and Deposition of Eustathius of Antioch, JTS 51 (2000) 150-160; P. Parvis, Constantine's Letter to Arius and Alexander?, StPatr 39 (2006) 89-95; S. Parvis, Marcellus of Ancyra and the lost years of the Arian controversy, Oxford 2006, Oxford University Press, 101-107. 
320s-330s. Correspondingly, Eustathius's deposition occupied Anglophone scholarship in the later twentieth century, even though it was otherwise not especially concerned with him. A large proportion of the scholarship is devoted to the elaborate task of reconstructing Eustathius's corpus. The lack of comparable attention to Eustathian theology owes much to the difficulty of this reconstruction and the sheer scarcity of the known sources. It is, therefore, unsurprising that there has been much fresh interest in Eustathius's thought since Declerck's publication of the epitomised Contra Ariomanitas.

Several editions and critical notes of Eustathius's works were produced in the eighteenth and nineteenth centuries ${ }^{6}$. Then, 1905 saw an explosion of scholarship relating to Eustathius, and formative to later discussion of him. Ferdinand Cavallera devoted considerable attention to Eustathius in his $\mathrm{Le}$ schisme d'Antioche, high-lighting his importance as an opponent of Arianism? In the same year, he published an edition of Homilia in Lazarum, Mariam et Martham, which he attributed to Eustathius ${ }^{8}$. This attribution has proved an abiding, though far from uncontroversial, legacy in Eustathian scholarship. Very shortly after Cavallera's publication, Louis Saltet argued that the homily's Trinitarian theology and Christology were often drastically anachronistic to the fourth century9. At the time, this seemed almost decisive, though the

${ }^{6}$ For a discussion of the various editions of Eustathius's work, cf. J.H. Declerck, Introduction, CCG 51, p. CIII-CXLV. Two editions of Eustathius's fragments were produced in the eighteenthcentury, first by Johann Albrecht Fabricius (Fragmente ex libris Eustathii Antiocheni deperditis in: Bibliotheca Graeca VIII, Hamburg 1717, 166-189), and later by André Galland (Fragmenta ex libris S. Eustathii episcope Antiocheni deperditis, in: Bibliotheca veterum Patrum IV, Venice 1768, 548-583). In 1804, Gottlieb Harles produced a revised edition of Fabricius' text (Bibliotheca Graeca IX, Hamburg 1804, 131-149). It was then over half a century before J.P. Migne published a further complete edition in: PG 161, Paris 1857, 676-697. In 1883, J.P. Paulin Martin (Analecta sacra Patrum antenicaenorum ex codicibus orientalibus collegit, IV, Parisiis 1883, 210-213 and 441-443) published ten Syriac fragments attributed to Eustathius, with a Latin translation. This included two (almost identical) fragments from a work against Photinus, the disciple of Marcellus of Ancyra. Contra Photinum was later to be deemed inauthentic, though the case for Eustathian authorship was revived by Rudolph Lorenz in 1980. See below. The following year, Jean Baptiste Pitra (Analecta Sacra Spicilegio Solemensi parata, II, Parisiis 1884, p. XXXVIII-XL) offered a further three Greek fragments, previously unattributed to Eustathius. In 1886, A. Jahn produced an edition of Eustathius's Engastrimytho contra Origenem (Des h. Eustathius Erzbischofs von Antiochien Beurtheilung des Origenes betreffend die Auffassung der Wahrsagerin I. Kön. (Sam.) 28 und die bezüngliche Homilie des Origenes aus der Münchner Hds. 331 ergänzt und verbesset mit kritischen und exegetischen Anmerkungen, TU 2, Leipzig 1886, J.C. Hinrichs), an attack on Origen's interpretation of 1 Kingdoms 28. Eustathius had attached Origen's own, otherwise lost, treatise on the subject, and this also appears in Jahn's edition.

${ }^{7}$ Cf. F. Cavallera, Le schisme d'Antioche, Paris 1905, Picard.

${ }^{8}$ Cf. Eustathius Antiochenus, Homilia in Lazarum, Mariam et Martham, ed. F. Cavallera: Saint Eustathii Episcopi Antiocheni in Lazarum, Mariam et Martham homilia christologica. Nunc primum e codice groviano edita cum commentario de fragmentis eustathianis; accesserunt fragmenta Flaviani I Antiocheni, Paris 1905, Picard.

${ }^{9}$ Cf. L. Saltet, Le schisme d'Antioch, BLE 8 (1906) 120-125. 
debate was to be reopened again by the discovery of a new manuscript ${ }^{10}$. To the Homilia in Lazurum, Cavallera attached most of the extant fragments, though he did not reproduce in full those that were available in print elsewhere.

In Le schisme d'Antioche, Cavallera offered a vivid picture of Eustathius's character and place in the Church of the 320 s, though he rightly acknowledged a great deal of uncertainty surrounding many of the details of Eustathius's life. He presented Eustathius and Marcellus of Ancyra as the champions of Nicene orthodoxy after the death of Alexander. Correspondingly, Cavallera's Eustathius is a tireless, recalcitrant, and uncompromising opponent of subordinationism. His wider understanding of the 'Arian' controversy is significant to the nuances of this picture. In contrast to some other scholarship, he makes a clear distinction between Arianism, per se, and a watered down version adhered to by the supporters of both Eusebiuses ${ }^{11}$. Eustathius, he claims, was a staunch opponent of both. Eusebius of Caesarea is presented as Eustathius's principal theological adversary, while Eusebius of Nicomedia is the political mastermind operating against him, and ultimately causing his downfall ${ }^{12}$.

Also in 1905, Eduard Schwartz produced a Syriac version of a synodal letter purporting to be from a council in Antioch, which he dated to $325^{13}$. This discovery was radically to alter our perception of the 'Arian' controversy. Significantly for our purposes, it brought Eustathius, bishop of Antioch, to the centre stage (confirming Cavallera's picture), though this did not in fact invigorate Eustathian scholarship in proportion to the fresh opportunities that the letter offered. Schwartz produced a Greek retroversion, which he acknowledged to be approximate, of the Syriac text. The initial response to Schwartz's publication was mixed. Adolf von Harnack claimed that the letter was a forgery ${ }^{14}$. Schwartz angrily defended the authenticity of his discovery,

${ }^{10}$ See discussion of M. Van Esbroeck below. In 1923, Friedrich Zoepfl (Die trinitarischen und christologischen Anschauungen des Bischofs Eustathius von Antiochien, ThQ 104:1923, 170-201, spec. 170-171) writes that the lack of knowledge of Eustathius's theology is largely due to there being only one full extant work, assuming rather than defending the truth of Saltet's claims.

${ }^{11}$ Cf. Cavallera, Schisme, p. 38. For scholarship that tends to see two ecclesial factions at Nicaea, cf. discussion of A.E. Burn, below. This picture is also key to S. Parvis's construction of the 'Arian' controversy (Marcellus of Ancyra, passim).

${ }^{12}$ F. Cavallera (Schisme, p. 36 and 38) does note that Eusebius of Caesarea was the one to accuse Eustathius at the council which deposed him, but sees this as part of a plan that Eusebius of Nicomedia was instrumental in creating.

${ }^{13}$ Cf. E. Schwartz, Zur Geschichte des Athanasius, VI: Die Dokumente des arianischen Streites bis 325, in: Nachrichten von der Königlichen Gesellschaft der Wissenschaften zu Göttingen. Philologisch-historische Klasse aus dem Jahre 1905, Göttingen 1905, 257-299, reprinted in: Gesammelte Schriften (= GS), III, Berlin 1959, Walter de Gruyter, 117-168; S. Parvis (Marcellus of Ancyra, p. 78) dates the Council of Antioch to December 324.

${ }^{14}$ Cf. A. von Harnack, Die angebliche Synode von Antiochia im Jahre 324-325, in: Sitzungsberichte der Königlich Preussichen Akademie der Wissenschaften, Berlin 1908, 477-491, reprinted in: Kleine Schriften zur alten Kirche, II, hrsg. von J. Dummer, Leipzig 1980, Zentralantiquariat der Deutschen Demokratischen Republik, 1-15. 
but Harnack stood his ground ${ }^{15}$. In 1913, Erich Seeberg surveyed the controversy surrounding the Council of Antioch and ultimately defended the authenticity of the synodal letter ${ }^{16}$. Some doubts about the authenticity of the letter still lingered, but Seeberg's work prompted a shift in the debate in favour of the letter's genuineness, and this is now widely accepted ${ }^{17}$.

Schwartz also made various attempts to reconstruct the events of Eustathius's life, within his extensive studies on the chronology of the 'Arian' controversy. Significantly, he argued for the Eustathian authorship of the pseudoAthanasian Sermo Major de Fide and Expositio Fidei, which had been found, by Jerome, in the same dossier in the Eustathian library at Antioch ${ }^{18}$.

Over a number of years, but also beginning at the turn of the last century, another German scholar, Friedrich Loofs, developed a picture of an 'Antiochene' theological school, in which he ultimately included Eustathius. In doing so, he offered categories for understanding Eustathius that were to recur, and be contested, in later scholarship ${ }^{19}$. Loofs' work on Eustathius particularly bears the mark of German Protestant scholarship in the late-nineteenth and early-twentieth centuries, in its search for 'biblical' Christianity, held in opposition to a corrupted, philosophising, Christian Platonism. His treatment can only be adequately understood within his wider picture of the development of Christian doctrine, and a connected long-term schism in the Church at Antioch.

He first became interested in Eustathius in developing and reworking Theodor Zahn's thesis on the 'Asia Minor' (kleinasiatisch or vorderasiatisch) tradi$\operatorname{tion}^{20}$. This tradition ostensibly focused on the historical Christ and took an economic approach to the Trinity, in contrast to the philosophising approach of the

${ }^{15}$ Cf. E. Schwartz, Zur Geschichte des Athanasius, VII: Das antiochenische Syndodalschreiben von 325, Nachrichten von der Königlichen Gesellschaft der Wissenschaften zu Göttingen. Philologisch-historische Klasse aus dem Jahre 1908, Göttingen 1908, 305-374 = GS III 169-187; A. von Harnack, Die angebliche Synode von Antiochien im Jahre 324-325 (2. Artikel), in: Sitzungsberichte der Königlich Preussichen Akademie der Wissenschaften, Berlin 1909, 401-425, reprinted in: Kleine Schriften zur alten Kirche, II, s. 16-40.

${ }^{16}$ Cf. E. Seeberg, Die Synode von Antiochien im Jahre 324/325, Berlin 1913, Trowitzsch.

${ }^{17}$ For a discussion of the response to Seeberg's monograph, cf. F.L. Cross, The Council of Antioch is 325 A.D., „Church Quarterly Review” 128 (1939) 49-76, spec. 49-53.

${ }^{18}$ Cf. E. Schwartz, Der s.g. Sermo major de fide des Athanasius, Münich 1924, Sitzungsberichte.

${ }^{19} \mathrm{~F}$. Loofs' picture is in turn determined by the construction of Eustathius in ancient sources, notably the Nestorian bias of Theodoret, who preserved a large portion of Eustathius's work. The connection that Loofs made between Eustathius and Paul of Samosata was also, of course, far from novel. Socrates (HE I 24, ed. Hansen, GCS NF 1) writes that Eustathius was accused of Sabellianism at the council that deposed him.

${ }^{20}$ F. Loofs first addressed the idea of the 'Asia Minor' tradition in the article Die Trinitätslehre Marcell's von Ancyra und ihr Verhältnis zur älteren Tradition, in: Sitzungsberichte der Königlich Preussischen Akademie der Wissenschaften. Phil-hist. Klasse, Berlin 1902, 764-781, and developed his thoughts on it over a number of years. His fullest treatment of Eustathius appears with his Paulus von Samosata. Eine Untersuchung zur altkirchlichen Literatur- und Dogmengeschichte, Leipzig 1924, J.C. Hinrichs' Buchhandlung. 
'Alexandrian' school ${ }^{21}$. Ignatius of Antioch, Irenaeus and Marcellus were key figures in Zahn's reconstruction ${ }^{22}$. Loofs reworked Zahn's thesis, focusing the tradition more specifically on Antioch. He ultimately concluded that the tradition was better labelled 'Antiochene', and added Eustathius ${ }^{23}$. Paul of Samosata was key in shaping Loofs' conception of this tradition (though Loofs claimed that Paul was less important than Eustathius to the later Antiochene School ${ }^{24}$. He draws a line between Tertullian and Nestorius, and sees Eustathius, along with Paul of Samosata, as one significant mediator between the two.

Loofs emphasises divine unity in Eustathius's theology, and cautiously concludes that Eustathius, like Paul of Samosata, believed that the Son went out from the Father at the time of the incarnation ${ }^{25}$. Much of the later scholarship that otherwise echoes Loofs has sought to qualify his reconstruction of Eustathius's Trinitarian doctrine by allowing for greater distinction between the Father and the Son $^{26}$.

The state of the Church at Antioch became a very important factor in the development of this tradition, in Loofs' revised understanding of it. The two theological schools juxtaposed by Zahn became two opposing ecclesial factions at Antioch in Loofs' thought. Cavallera had dated the schism from Eustathius's deposition ${ }^{27}$. Conversely, Loofs argues that the Church in Antioch had been divided since the time of Paul of Samosata, and had had 'Antiochene', or 'Paulinist', and Origenist, or 'catholic', bishops ${ }^{28}$. Eustathius succeeded to Antioch as the bishop of both factions and briefly held together a fragile truce.

In 1923, Friedrich Zoepfl also linked Eustathius to 'Asia Minor' theology, in an article examining his Trinitarian theology and Christology ${ }^{29}$. In Zoepfl's view, Asia Minor's mark on Eustathius was evident in his strong soteriological

${ }^{21}$ The treatment of the 'Asia Minor' tradition in German scholarship has received some recent attention, thanks to the revival of interest in another of its purported adherents, Marcellus of Ancyra, cf. J. Lienhard, Marcellus of Ancyra in Modern Research, ThS 43 (1982) 486-503.

${ }^{22}$ Cf. Th. Zahn, Marcellus von Ancyra: ein Beitrag zur Geschichte der Theologie, Gotha 1867, F.A. Perthes.

${ }^{23}$ Eventually, as he drafted Eustathius into the tradition, Loofs changed his mind about Marcellus's theology, deciding that Marcellus echoed Origenism as much as he did the Antioch. In this way, Loofs ended up emphasising significant differences between the theology of Marcellus and Eustathius.

${ }^{24}$ Cf. Loofs, Paulus von Samosata, p. 294. Following the suggestion of Leontius, Adolf von Harnack connected Paul of Samosata with the later Antiochene tradition, cf. ibidem, p. 293-294.

${ }^{25}$ Cf. ibidem, p. 296-300.

${ }^{26}$ See discussions on Zoepfl, Sellers and Lorenz, below.

${ }^{27}$ Cf. Cavallera, Schisme, p. 43.

${ }^{28}$ Cf. Loofs, Paulus von Samosata, p. 180-186.

${ }^{29} \mathrm{Cf}$. Zoepfl, Die trinitarischen und christologischen Anschauungen, passim. My chronology here reflects the fact that Zoepfl's interest in Eustathius began later than Loofs', particularly because Loofs' wider work on 'Asia Minor' or 'Antiochene' theology is important to his analysis of Eustathius, but it should be noted that he was still to publish Paulus von Samosata (see note 20), in which he discusses Eustathius at length. 
emphasis on Christ's humanity which echoed the concept of recapitulation ( $\alpha \nu \alpha \kappa \varepsilon \varphi \alpha \lambda \alpha i \omega \sigma ı \varsigma)$ found in Ignatius and Irenaeus ${ }^{30}$. This emphasis, Zoepfl claimed, was particularly reflected in Eustathius's belief in Christ's human $\operatorname{soul}^{31}$. Zoepfl further noted what he saw as a corresponding sense that Christ's humanity renders God visible. However, he also found Origenist Platonism in Eustathius's Christology. Ironically, he found this to be evident specifically in Eustathius's concept of Christ's human soul because it mediates between the Logos and the material world and correspondingly undermines the sense that Christ's humanity is what makes the Logos visible ${ }^{32}$. Zoepfl thus depicted Christ's human soul as pulling in two different directions in Eustathius's Christology, but had the sense that the Eustathian dogma of Christ's human soul was inextricably linked to Origenism.

Zoepfl declined to label Eustathius Nestorian, but did note several parallels in the two men's Christology. In Zoepfl's view, it is only possible to speak of „Menschwerdung” - of God becoming human - in a very loose sense in Eustathius's Christology; Eustathius, rather, conceives of the Logos as dwelling in, or putting on, the human Jesus ${ }^{33}$. Zoepfl was more firmly persuaded that Eustathius was not a Sabellian than that he was not proto-Nestorian; he believed that Eustathius's Logos theology diverged sharply from Paul of Samosata's, because, for Eustathius, the Logos had a separate, personal existence ${ }^{34}$. In this respect his picture is very different from Loofs'. Zoepfl subsequently wrote on the pseudo-Eustathian Hexameron, arguing persuasively that it was written too late to be Eustathian ${ }^{35}$.

Shortly after Zoepfl's article and Loofs' monograph, Andrew Burn gave a lecture on Eustathius, in English ${ }^{36}$. His picture of Eustathius's life largely echoed Cavallera's: Eustathius is starkly opposed not only to Arius, but also to both Eusebiuses and their supporters, and he is deposed as a consequence of the Eusebian party's duplicitous machinations ${ }^{37}$. Burn also followed the recent German scholarship in defining Eustathius as an Antiochene theologian ${ }^{38}$.

${ }^{30} \mathrm{Cf}$. Zoepfl, Die trinitarischen und christologischen Anschaunngen, p. 201. For the 'Asia Minor' tradition in Eustathius, see also ibidem, p. 182. The concept of ó $v \alpha \kappa \varepsilon \varphi \alpha \lambda \alpha$ í $\omega \sigma ı \varsigma$ in Irenaeus is well documented, cf. E. Osborn, Irenaeus of Lyons, Cambridge 2001, Cambridge University Press, 97-140.

${ }^{31}$ Cf. Zoepfl, Trinitarischen und christologischen Anschauungen, p. 198.

${ }^{32}$ Cf. ibidem, p. 188-189.

${ }^{33}$ Cf. ibidem, p. 195.

${ }^{34}$ Cf. ibidem, p. 178: „Der Logos ist für Eustathius ein persönlich abgeschlossenes Wesen”.

${ }^{35}$ Cf. F. Zoepfl, Der Kommentar des Pseudo-Eustathios zum Hexaëmeron, Münich 1927, Aschendorf.

${ }^{36}$ Cf. A. Burn, Saint Eustathius of Antioch, Nicene Lectures 1, London 1926.

${ }^{37} \mathrm{Cf}$. ibidem, p. 6-9. Because he is aware of the Council of Antioch, Burn is more decided than Cavallera in placing all of Eustathius's subordinationist opponents in one theological camp: „there were only two parties [at Nicaea], for and against Arius", see ibidem, p. 9.

${ }^{38}$ Cf. ibidem, p. 20. 
However, he explicitly defended Eustathius's Chalcedonian orthodoxy, taking a two-pronged approach (and risking self-defeat in the process). He argued both that Eustathius's divisive Christology was merely speculative, whereas Nestorious attacked the Church's doctrine, and that Eustathius, anyway, saw Christ as ,perfect God and perfect man" 39 . A confessional, in this case Anglican, influence is, of course, as evident in Burn's dissociation between Eustathius and Nestorius as it was in Loofs' enthusiastic connections between them.

In 1928, Robert Sellers produced what remains the only monograph on Eustathius's theology in English ${ }^{40}$. He also included a substantial discussion of Eustathius in his later Two Ancient Christologies ${ }^{41}$. In both works, he juxtaposed Antiochene theology with Alexandrine theology, and saw them as competitors within the history of Christian doctrine. According to Sellers, Antiochene theology was defined by dyohypostatic Christology and literalist exegesis. Sellers placed Eustathius squarely within the 'Antiochene' tradition, and drew a direct line between Paul of Samosata, Eustathius and Nestorius ${ }^{42}$.

Sellers's treatment of Eustathius echoed the then recent German scholarship, though he placed less emphasis on economic Trinitarianism than the German tradition had done, and did not connect Eustathius with Irenaeus. In Sellers, the 'Antiochene' tradition had lost the resemblance to Zahn's 'Asia Minor' tradition that it had had in Loofs. This appears to be a logical (though not necessary) development of Loofs' focus on Antioch as the hub of this tradition. However, Sellers also followed Zoepfl, who had retained the descriptor 'Asia Minor', more closely than Loofs, in important respects: Sellers, like Zoepfl, believed that Eustathius allowed the Son a personal existence where Paul of Samosata did not. He criticised Loofs for failing to appreciate this. For Eustathius ,the eternal Logos is 'Son' - 'the Son' is not set up with the indwelling of Wisdom in the Man" and ,for Eustathius, the Son has His own hypostasis"43. Sellers felt that Eustathius's theology was superior to Paul's in this respect. Like Loofs, Sellers saw something valuable in the 'Antiochene' tradition, and wished to safeguard its distinctiveness. This sometimes led to a problematically circular method of determining which works were authentically Eustathian ${ }^{44}$.

${ }^{39}$ Ibidem, p. 15 and 22 respectively. He additionally allows that historiography may have been unfair in its analysis of Nestorius's Christology.

${ }^{40} \mathrm{Cf}$. R. Sellers, Eustathius of Antioch and his place in the early history of Christian doctrine, Cambridge 1928, Cambridge University Press.

${ }^{41}$ Cf. R. Sellers, Two Ancient Christologies, London 1940, Society for the Promotion of Christian Knowledge.

${ }^{42}$ Cf. ibidem, p. 107-108.

${ }^{43}$ Cf. ibidem, p. 122 and 123 respectively.

${ }^{44}$ For example, he rejects the authenticity of a section of a putatively Eustathian fragment on Melchizedek, on the basis that it „confuses the natures of Christ”, thus making divisive Christology an a priori requirement for Eustathian authorship, cf. Sellers, Eustathius of Antioch, p. 69. 
Several pieces of close textual scholarship were also produced in the first few decades of the twentieth century: Erich Klostermann published an edition of Engastrimytho in 1912, together with Origen's and Gregory of Nyssa's treatises on the subject ${ }^{45}$. In 1924, Ludwig Radermacher wrote an article tracing the use of Plato and Sophocles in Engastrimytho ${ }^{46}$; and in 1933, Wilhelmine Brockmeier produced a detailed word index of Engastrimytho and included a discussion of the work's structure, noting, in particular, its atticising style ${ }^{47}$. 1933 also saw the publication by Ignaz Rucker of a critical edition of the anti-'Nestorian', Florilegium Edessenum anonymum, preserved in Syriac, which was already known to contain four putatively Eustathian fragments. Together with notes on the fragments, Rucker produced a Greek retroversion ${ }^{48}$.

In an article published in 1940, Berthold Altaner defended the authenticity of a collection of ostensibly Eustathian fragments on Melchizedek, one of which is ascribed to a letter to Alexander of Alexandria on this subject ${ }^{49}$. Altaner argued persuasively that they did indeed originate from this work, and this has been widely accepted ${ }^{50}$. He further offered many observations about the interrelation of the Melchizedek fragments and asserted that the argumentation of this work could be seen clearly from its extant portion.

Michel Spanneut is the foremost Eustathian scholar of the twentieth century. He produced a major edition of Eustathius's works, with an extensive introduction, in $1948^{51}$. He also wrote several articles on Eustathius ${ }^{52}$. In his edition, he rejected the Eustathian authorship of Sermo Major de Fide and Expositio Fidei, proposed by Schwartz, arguing that they became attributed to Eustathius via Jerome's misattribution to Athanasius ${ }^{53}$.

${ }^{45} \mathrm{Cf}$. E. Klostermann, Origenes, Eustathius von Antiochien und Gregor von Nyssa über die Hexe von Endor, Kleine Texte für Vorlesungen und Übungen 83, Bonn 1912, A. Marcus und E. Weber.

${ }^{46}$ Cf. L. Radermacher, Eustathios von Antiochien, Platon und Sophokles, „Rheinisches Museum für Philologie N.F." 73 (1924) 445-449.

${ }^{47}$ Cf. W. Brockmeier, De Sancti Eustathii episcopi Antiocheni dicendi ratione. Accedit index vocabulorum libri contra Origenem scripti omnium, Borna - Leipzig 1933.

${ }^{48}$ Cf. I. Rucker, Florilegium Edessenum anonymum, Sitzungsberichte der Bayerischen Akademie der Wissenschaften. Philosophisch-historische Abteilung 5, Münich 1933.

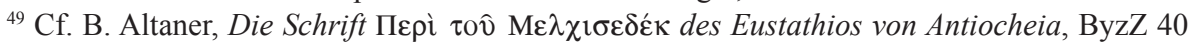
(1940) 30-47.

${ }^{50}$ Cf. Declerck, Introduction, CCG 51, p. CCCCXI-CCCCXII. R. Sellers (Eustathius of Anti$o c h$, p. 69; see also note 40 and 44 above) had earlier expressed doubt about the authorship of the Greek fragments attributed to Eustathius.

${ }^{51}$ Cf. M. Spanneut, Recherches sur les écrits d'Eustathe d'Antioche, Lille 1948, Facultés Catholiques.

${ }^{52}$ Cf. M. Spanneut, Eustathe d'Antioche exegete, StPatr 7 (1966) 549-559; Eustathe d'Antioche, DHGE XVI 13-23; Hippolyte ou Eustathe? Autour de la Chaîne de Nicétas sur l'Évangile selon saint Luc, MSR 9 (1952) 215-220; La Bible d'Eustathe d'Antioche, StPatr 4 (1961) 171-190; La position theologique de Eustathe d'Antioch, JTS NS 5 (1954) 220-224.

${ }^{53}$ Cf. idem, Recherches, p. 87-89; see also note 49. 
One article focused on exegesis in Engastrimytho, and marked a turning point in the understanding of Eustathius as an 'Antiochene' exegete, which was itself part of a wider development in the study of patristic exegesis ${ }^{54}$. Though Spanneut sees significant parallels between Eustathius's exegesis and that of later theologians often associated with Antioch, such as Theodore and Diodore, his picture of Eustathian exegesis complicates the category 'literalist': Eustathius, he argues ,condemns a literalist conception of inspiration [of scripture] which, wrongly or rightly, he attributes to Origen" ${ }^{55}$. He argues that Eustathius criticised Origen primarily for failing to regard scripture holistically ${ }^{56}$. Correspondingly, his approach to the question of Eustathius's 'Antiochene' status, and his conclusions, differ from Sellers' in important ways. He starts from an exposition of Eustathius's exegesis, and moves to a comparison with Theodore and Diodore, rather than rooting Eustathius, from the outset, in this later tradition. Spanneut's analysis thus avoids the sometimes problematic tendency to interpret Eustathius in light of later thinkers and discourses, found in Sellers.

Spanneut remained, until very recently, the last scholar to write extensively on Eustathius, but the next five decades were to witness sporadic interest in the contents of the Eustathian corpus and rather more persistent interest in the date and nature of his deposition. He otherwise appeared in works on other aspects of the 'Arian' controversy as an example of an 'extreme' Nicene, often compared to Marcellus of Ancyra or occasionally as an example of fourthcentury anti-Origenism ${ }^{57}$.

Shortly after the appearance of Spanneut's critical edition, Felix Scheidweiler wrote a series of articles on Eustathius, largely focusing on his corpus, and was, at least at first, more persuaded by Schwartz than by the more recent work of Spanneut. He initially accepted the Eustathian authorship of Sermo Major de Fide and Expositio Fidei and introduced the argument that Eustathius was the author of Contra Theopaschitas ${ }^{58}$. He based his claim very largely on the similarity between it and the other two works. Accepting Eustathian authorship of these works supposes that Eustathius was still alive after the Council of Serdica, which Scheidweiler argues on the basis that he wrote Contra Photinum, which also clearly post-dates Serdica ${ }^{59}$. Scheidweiler later

\footnotetext{
${ }^{54} \mathrm{Cf}$. idem, Eustathe exegete, passim; see also note 50.

${ }^{55} \mathrm{Cf}$. ibidem, p. 553: „Eustathe condamne une conception littéraliste de l'Inspiration, qu'à tort ou à raison, il attribue à Origène".

${ }^{56}$ Cf. ibidem, p. 553.

${ }^{57}$ Cf. Hanson, The Search, p. 208-217; J. Dechow, Dogma and Mysticism in Early Christianity: Epiphanius of Cyprus and the Legacy of Origen, Macon GA 1988, Mercer University Press, 114-125 respectively. Dechow approaches Eustathius as an influence on Epiphanius.

${ }^{58}$ Cf. F. Scheidweiler, Ein Glaubensbekenntnis des Eustathius von Antiochen?, ZNW 44 (1952/1953) 237-249.

${ }^{59} \mathrm{Cf}$. ibidem, p. 242. Photinus did not come to prominence until the 340 s.
} 
attributed all three works to Marcellus of Ancyra ${ }^{60}$. He additionally proposed several emendations to Spanneut's edition of the fragments ${ }^{61}$.

Two collaborative works from the 1970s are significant to the work on Eustathius's Syriac fragments and therefore merit mention. Luise Abramowski and Albert Van Roey produced a critical note on a Nestorian collection of Syriac fragments, containing five fragments by Eustathius ${ }^{62}$. Two years later, Abramowski and Alan Goodman produced the two volume work, A Nestorian Collection of Christological Texts, again containing Eustathian fragments ${ }^{63}$. It included the Syriac text and an English translation.

Aloys Grillmeier rejected the picture of Eustathius as proto-Nestorian in his Christ in the Christian Tradition ${ }^{64}$. Grillmeier notes the more unitive Christology in a few, probably early, fragments and describes the theology in them as ,completely un-Antiochene, in the later sense of the word" 65 . Eustathius's Christology did later become divisive, he claims, in response to Arianism: Eustathius noticed that Logos-sarx Christology, favoured by the 'Arians', required the Logos to be the subject of Christ's passions, and therefore undermined the Logos' divinity. Eustathius clearly articulated Christ's human soul to guard against this Arian position ${ }^{66}$. By emphasising the defensive context of Eustathius's divisive Christology, Grillmeier seeks to place it in the realm of emphasis rather than dogma.

In 1975, Michel van Esbroeck reopened the debate about the Eustathian authorship of Homilia christologica in Lazarum, Mariam et Martham in a mon$\operatorname{ograph}^{67}$. He published a further article on the subject in $1982^{68}$. He based his argument on a Georgian version of the text, which had been discovered in

${ }^{60}$ Cf. F. Scheidweiler, Wer ist der Verfasser des sog. Sermo Maior de Fide, ByzZ 47 (1954) 333-357. As Joseph Lienhard has observed, this was part of move in a radically new direction within Marcellan scholarship, see Lienhard, Marcellus of Ancyra's, p. 495-496.

${ }^{61}$ Cf. F. Scheidweiler, Die Fragmente des Eustathios von Antiocheia, ByzZ 48 (1955) 73-85.

${ }^{62}$ Cf. L. Abramowski - A. Van Roey, Das Florileg mit den Gregor-Scholien aus Vatic. Borg. Syr. 82, „Orientalia Lovaniensia Periodica” 1 (1970) 131-180. The fragments in question are D80, D81b, D84, D124b, D126.

${ }^{63}$ Cf. L. Abramowski - A. Goodman, A Nestorian Collection of Christological Texts, Cambridge 1972, Cambridge University Press. The fragments in question are D81, D124, D125.

${ }^{64}$ This work was originally written in German and appeared in two editions, both of which were translated into English. The treatment of Eustathius can be found in: A. Grillmeier, Christ in the Christian Tradition, transl. J. Bowden, vol. 1, London - Oxford 1975, Mowbrays, 296-301.

${ }^{65}$ Ibidem, p. 297-299, quote 297. Grillmeier's use of the term 'Antiochene' cautiously affirms its usefulness as a descriptor of Eustathius's anti-Arian Christology, even whilst approaching it with considerable trepidation.

${ }^{66}$ Cf. ibidem, p. 299-300. There is one particular fragment in which Eustathius explicitly makes this accusation against his opponents, D119b. Hanson draws on Grillmeier's argument that Eustathius opposed Logos-sarx Christology to safeguard the impassibility of the Logos, see note 57.

${ }^{67} \mathrm{Cf}$. M. van Esbroeck, Les plus anciens homéliares georgiens. Étude descriptive et historique, Louvain 1975, Institut Orientaliste de Louvain.

${ }^{68}$ Cf. M. Van Esbroeck, L'homélie d'Eustathe d'Antioche en géorgien, OC 66 (1982) 189-214. 
1930. Van Esbroeck argued that the Georgian manuscript was closer to the original Greek and showed that the original was, after all, Eustathian.

In 1980, Lorenz defended the Eustathian authorship of Contra Photinum (which had been more assumed than defended by Scheidweiler) ${ }^{69}$. The silence surrounding Eustathius after his deposition is often considered compelling evidence of his relatively early death, but Lorenz argues that it can be explained by the fact that he insulted Helena, and was therefore destined to remain a persona non grata for the entire Constantinian dynasty ${ }^{70}$.

The extant fragments of Contra Photinum defend the author against the charge of believing in ,three Gods" and maintain some clear distinction between $v \pi$ ó $\sigma \tau \alpha \sigma i \varsigma$ - of which there is only one - and $\pi \rho o ́ \sigma \omega \pi \mathrm{ov}$ - of which there are three - in the Godhead ${ }^{71}$. Therefore, in arguing that the Trinitarian theology of Contra Photinum is that of Eustathius, Lorenz qualifies Eustathius's emphasis on divine unity, echoing both Zoepfl and Sellers. He defends his attribution to Eustathius of a distinction between $v \pi$ ó $\sigma \tau \alpha \sigma \iota \varsigma$ and $\pi \rho o ́ \sigma \omega \pi \mathrm{ov}$ by arguing that the use of $\pi \rho \sigma^{\sigma} \sigma \pi \mathrm{ov}$, in Contra Photinum, to refer to God's nature, echoes Eustathius's use of 'siov to refer to God's nature in Engastrimytho ${ }^{72}$.

Both strands of Lorenz's argument relatively downplay the relationship between theology and politics in shaping the 'Arian' controversy. The theological disagreement between Photinus and Eustathius overrode their anti-Arian alliance, and Eustathius's deposition was firmly in the realm of imperial politics, to the extent that alterations in the relationship between the imperial administration and his theological faction did not affect it.

In the later twentieth century, there was some consideration of Eustathius's exegesis and in particular his place in the history of exegesis, focusing on Engastrimytho: in 1989 Manilo Simonetti produced a new edition of Engastrimytho, together with the respective treatments of Origen and Gregory of Nyssa on the same text ${ }^{73}$. Joseph Trigg shortly afterwards wrote an article examining the nature of Eustathius's disagreement with Origen. He follows Spanneut in accepting that Eustathius and Origen represented opposed exegetical traditions but questioning the use of a dichotomy between literalism and allegory in understanding these traditions ${ }^{74}$. The work of Simonetti and Trigg was part of a wider interest in the categories of 'Antiochene' and 'Alexandrian'

\footnotetext{
${ }^{69}$ Cf. R. Lorenz, Die Eustathius von Antiochien zugeschriebene Schrift gegen Photin, ZNW 71 (1980) 109-128.

${ }^{70}$ Cf. ibidem, p. 110. For Eustathius's death prior to 337, cf. Cavallera, Schisme, p. 41.

${ }^{71}$ The fragments are D142a-c.

${ }^{72}$ Cf. Lorenz, Die Eustathius von Antiochien, p. 121. For Eustathius's use of 'ídıv, Lorenz cites De Engastrimytho contra Origenem 30, 6.

${ }^{73}$ Cf. M. Simonetti, La Maga di Endor: Origene, Eustazio, Gregorio di Nissa, Biblioteca Patristica 15 Firenze 1989, Nardini.

${ }^{74} \mathrm{Cf}$. J. Trigg, Eustathius of Antioch's attack on Origen: what was at issue in an ancient controversy?, „The Journal of Religion” 75 (1995) 219-238.
} 
in Christian exegesis in the third and fourth centuries, and an interest in readings of the witch of Endor narrative ${ }^{75}$.

The last sixty years have seen significant discussion of Eustathius's accession and, even more so, his deposition, in Anglophone scholarship. It is now conventional to date Eustathius's accession to the See of Antioch to the Council of Antioch in 324/325 $5^{76}$. However, Paul Parvis has recently questioned this thesis ${ }^{77}$. His argument is closely connected to a wider uncertainty surrounding the episcopal succession in Antioch, and in some ways develops Loofs' work on the schism at Antioch.

The chronology of the bishops of Antioch in the 320s has long been confused, principally because, whilst some ancient sources refer to Paulinus of Tyre as Eustathius's predecessor, others refer to him as Eustathius's successor, and this latter claim has been widely accepted ${ }^{78}$. Philogonius of Antioch is, consequently, seen as Eustathius's predecessor. However, Richard Burgess has argued that there would not have been time for Paulinus's episcopate if he had succeeded Eustathius, and therefore believes that Paulinus was, after all, Eustathius's predecessor ${ }^{79}$. It is known that Philogonius died on $20^{\text {th }}$ December, because this is his feast day. Much scholarship has assumed that this was December 324. However, Burgess places Philogonius's death on 20 December 323 , a year earlier than the conventional date ${ }^{80}$.

${ }^{75}$ Cf. K.A.D. Smelik, The Witch of Endor: 1 Samuel 28 in Rabbinic and Christian exegesis till 800 A.D., VigCh 33 (1979) 160-179; N. Frye, The great code: the Bible and literature, London 1983, Ark Paperbacks; M. Simonetti, Biblical interpretation in the early Church, transl. J.A. Hughes, Edinburgh 1994, T and T Clark; F. Young, Biblical Exegesis and the formation of Christian culture, Cambridge 1997, Cambridge University Press.

${ }^{76}$ Cf. R. Williams, Arius Heresy and Tradition, Student Christian Movement, London 2001, 58. On Antioch, see discussion about Schwartz's discovery of the synodal letter, above.

${ }^{77}$ Cf. Parvis, Constantine's Letter, p. 89-95.

${ }^{78}$ R. Burgess (Studies in Eusebian and post-Eusebian chronography, Stuggart 1999, Franz Steiner, 184-191) discusses the evidence in detail and I draw here on his analysis. For example: Jerome (Chronicon 232c) and Theophanes (Chronicon 11, 30; 13, 27; 15, 17) name Paulinus as Eustathius's predecessor; Eusebius (Contra Marcellum I 4, 2) and Theodoret (HE I 22) both list that Paulinus succeeded Eustathius. Philostorgius (HE II 7; III 15 and XV) writes that Paulinus was the predecessor of Eulalius, who was bishop after Eustathius, thereby also suggesting that Paulinus was Eustathius's successor. A few of the sources placing Paulinus directly before Eustathius are somewhat confused about Paulinus's name because of transcriptional error. For example: Chronicle 724 refers to „Flavianus”, but this clearly leads us back to Paulinus when one considers the similarity of the names 'Paulinus' and 'Flavinius' in Syriac. Jacob of Edessa also says that Paulinus succeeded Eustathius, but sees him as a rival „orthodox” bishop to the pro-Arian Eulalius. R. Burgess (Studies, p. 185) convincingly argues that Jacob has confused Paulinus I with Paulinus II, who was bishop of Antioch from 362-380 and whose title, according to Socrates (HE V 5, 4), was contested by Meletius. Details of the council, and what it can tell us about Eustathius, are discussed below.

${ }^{79}$ On which, see below.

${ }^{80}$ Cf. Burgess, Studies, p. 186-187. R. Sellers had earlier suggested this reconstruction in his work Eustathius of Antioch (p. 21-22). 
Paul Parvis has developed Burgess's thesis in a different direction, which in some ways reinvigorates Friedrich Loofs' picture of a schism at Antioch, but ties it more closely to the 'Arian' controversy ${ }^{81}$. Loofs had suggested that Paulinus was the 'Paulinist' bishop of Antioch, rivalling Philogonius, the 'Catholic' bishop. Parvis also invokes a divided house at Antioch, but suggests that Eustathius and Paulinus, rather than Philogonius and Paulinus, were simultaneous, rival bishops. He argues that Constantine's so-called „letter to Arius and Alexander" suggests that there were two rival bishops of Antioch at the time of writing, and that this remained the case ${ }^{82}$; this is why Constantine never travelled east. So, in Parvis's view, Eustathius was a bishop of Antioch from the death of Philogonius in 323, and the (strongly anti-'Arian') Council of Antioch asserted his legitimacy over that of Paulinus. Paulinus was then recognised as bishop of Antioch by the emperor after Eustathius's deposition.

The arguments about Eustathius's deposition are generally well known and it would be superfluous to reproduce them here ${ }^{83}$. Suffice to note the key trends: firstly dates ranging from 326 to 331 have all been suggested for the deposition, but 327-328 has emerged as almost conclusive ${ }^{84}$. Secondly, a significant fault-line in this debate is the relationship between Eustathius's deposition and Constantine's change of mind in favour of the Eusebians. Most modern scholars have supposed that it was a consequence of this change of mind, but Rowan Williams and Sara Parvis both see it as triggering the change ${ }^{85}$.

As aforementioned, José Declerck's edition of the entire Eustathian corpus came out in 2002. It included an anti-subordinationist epitome entitled Contra Ariomanitas et de anima ${ }^{86}$. The attribution is based primarily on the undeniable identity between sections of the epitome and Eustathian fragments preserved by Theodoret of Cyrus, which all previous scholars of Eustathius's corpus have deemed reliable. Declerck also argued against the Eustathian authorship of Homilia in Lazarum, persuasively demonstrating that many anachronisms

${ }^{81}$ Cf. Parvis, Constantine's Letter, passim.

${ }^{82}$ F. Loofs had also pointed to Jerome's belief that Paulinus preceded Eustathius as suggesting a „Paulianisch” bishop of Antioch, following the tradition of Paul of Samosata, whilst Philogonius was the „katholisch” bishop of Antioch. This theory was based on his belief in a long-standing schism in Antioch, since the time of Paul of Samosata, see Loofs, Paulus von Samosata, p. 186-187, and my discussion above.

${ }^{83}$ See note 5 for a list of the discussions.

${ }^{84}$ Cf. Chadwick (The Fall, passim), for a 326 date, and Hanson (The Search, p. 210), for a date of 331. Barnes (Emperor and Bishops, passim) argued for 327. Subsequently, Burgess (Date and Deposition, passim) argued for 328, but S. Parvis (Marcellus of Ancyra, p. 101-107) argued again for 327 . Barnes, S. Parvis and Burgess between them conclusively rule out the very early and very late suggestions of Hanson and Chadwick.

${ }^{85}$ Cf. Williams, Arius, p. 74.

${ }^{86}$ See above note 1. For Declerck's discussion of the epitome, cf. especially ibidem, Introduction, p. CLIV-CLXXXI. 
exist in the Georgian text. He additionally rejected the authenticity of Contra Photinum $^{87}$.

Following the publication of this new edition, there are many signs of growing interest in Eustathius. Robert Greer and Margaret Mitchell have recently published a new edition of Engastrimytho, together with an English translation, which forms part of a wider study on patristic exegesis of 1 Kingdoms $28^{88}$. Mitchell also published a highly-related article on the Engastrimytho, examining Eustathius's debt to rhetorical handbooks in his attack on Origen ${ }^{89}$. Though the context of Declerck's critical edition is doubtless significant, these works continue a trend begun before Declerck's publication in their obvious interest in Eustathius as a figure within the history of Christian exegesis, and in the Witch of Endor text.

In his monograph, Nicaea and its Legacy, Lewis Ayres categorised Eustathius, along with Marcellus, as a „theologian of the Undivided Monad" placing Eustathian theology within a fresh theological understanding of the 'Arian' controversy $^{90}$. Sara Parvis reopened, though did not develop, the question of Eustathius's relationship to the 'Asia Minor' tradition in her monograph on Marcellus of Ancyra ${ }^{91}$. In particular, she noted parallels between Eustathius's conception of the image of God and that in both Marcellus and Irenaeus ${ }^{92}$. She also suggested that Marcellus and Eustathius had a very similar doctrine of God, but that, although both can in different ways be accused of protoNestorianism, Marcellus also has some strong similarities with Athanasius, absent in Eustathius.

A series of articles on Eustathius has also followed Declerck's publication. The Jesuit scholar Patricio de Navascués has written two articles about Ariomanitas. In the first, he considered its philosophical currents and argued that Eustathius was significantly at odds with both Platonism and Stoicism but had much in common with Aristotelianism. He identified in Ariomanitas a particular strand of Peripatetic thought, influenced by Stoicism and criticised by Alexander of Aphrodisias ${ }^{93}$. In his second article, Navascués characterised Eustathius as an 'Antiochene' theologian and argued that the key to Ariomanitas was the glorified body of the ascended Christ; Eustathius emphasised this in opposition

${ }^{87}$ Cf. ibidem, p. CCCCXX-CCCCLXII.

${ }^{88} \mathrm{Cf}$. R. Greer - M. Mitchell, The Belly-Myther of Endor: interpretations of 1 Kingdoms 28 in the Early Church, Atlanta 2006, Society of Biblical Literature.

${ }^{89}$ Cf. M. Mitchell, Rhetorical handbooks in Service of Biblical Exegesis: Eustathius of Antioch takes Origen back to school, in: The New Testament and Early Christian Literature in GrecoRoman Context, ed. by J. Fotopoulos, Supplements to Novum Testamentum 122, Leiden 2006, Brill, 349-367.

${ }^{90}$ Cf. L. Ayres, Nicaea and its Legacy, Oxford 2004, Oxford University Press, 63.

${ }^{91}$ Cf. Parvis, Marcellus of Ancyra, p. 57-60.

${ }^{92} \mathrm{Cf}$. ibidem, p. 58.

${ }^{93}$ P. de Navascués, El sustrato filosófico de la obra de Eustacio de Antioquia, TyV 48 (2007) 149-166. 
to Neo-Platonic elements of Arian theologian ${ }^{94}$. In his second article, Navascués stops short of repudiating his former conclusions about Eustathius's Aristotelianism. However, he self-consciously moves away from a 'philosophical' understanding of Eustathius towards a 'theological' understanding, rather than exploring another facet of Eustathius's thought. In his contrast between 'philosophical' and 'theological', Navascués employs categories that have been problematized by successive scholars who have emphasised the interrelation of the two in patristic thought. He also employs that category 'Antiochene', more or less as it was used by Loofs, but does not connect it with Irenaeus; Navascués also refers to Irenaeus and Asia Minor theology, but as a separate, and lesser, influence on Eustathius ${ }^{95}$. This reflects, among other things, the extent to which his treatment of Eustathius focuses on Christology.

Karl-Heinz Uthemann wrote an article exploring pro-Arian Christology in light of Eustathius's attack, in Ariomanitas, on the Logos-sarx Christology of pro-Arianism ${ }^{96}$. Uthemann argues that Eustathius's opponents promoted a Logos who was sinless and impassible through choice, and in doing so gave to the Word the place that Origen had given to Christ's human soul - Eustathius responds that Christ's human soul ought to have this place itself. In making his argument, Uthemann foregrounds the evidence of the Council of Antioch $324 / 325$, which condemned the belief that the Son was immutable through his own will. This is the first piece of work focusing on the way in which the new epitome of Ariomanitas is significant for our understanding of pro-Arian theology and also makes invaluable contributions to our understanding of Eustathius's Christology.

Uthemann's work has several important implications for a reconstruction of the 'Arian' controversy. Firstly, it lends itself to an understanding of the 'Arian' controversy as being a consequence of Origen's legacy. Secondly, it reinvigorates the thesis of Robert Gregg and Denis Groh: that Arianism was soteriologically motivated, and required a saviour who could progress morally ${ }^{97}$.

Subsequently, Kelley Spoerl has written two articles on Eustathius ${ }^{98}$. The first compares the doctrine of God and Christology in Eustathius and Marcellus.

\footnotetext{
${ }^{94} \mathrm{Cf}$. idem, 'Cuerpo'en la tradición antioqena, „Augustinianum” 51 (2011) 21-45.

${ }^{95}$ Cf. ibidem, p. 29.

${ }^{96}$ Cf. K.H. Uthemann, Eustathios von Antiochien wider den seelenlosen Christus der Arianer. Zu neu entdeckten Fragmenten eines Traktats des Eustathios, ZACh 10 (2007) 472-521.

${ }^{97}$ Cf. R. Gregg - D. Groh, Early Arianism: a view of salvation, Philadelphia 1981, Fortress Press. Correspondingly, Stuart Hall (The Nicene Creed as a symbol of unity in Christology in: Jesus Christ today: studies of Christology in various contexts, ed. by S. Hall; Berlin 2009, Walter de Gruyter, 2009, 89-104, spec. 101-102) briefly discusses Eustathius's Christology, citing Uthemann's work, noting that Contra Ariomanitas suggests that we should see early Arianism as driven by Christological and soteriological concerns, more than strictly theological ones.

${ }^{98} \mathrm{Cf}$. K. Spoerl, Two early Nicenes: Eustathius of Antioch and Marcellus of Ancyra, in: In the Shadow of the Incarnation: essays in honour of Brian E. Daley S.J., ed. by P.W. Martens, Notre
} 
Spoerl's point of comparison is determined more by the two thinkers' putatively extreme position within the Nicene alliance, than by any potential connection with Irenaeus, and an older 'Asia Minor' or 'Antiochene' tradition. Spoerl argues that Eustathius and Marcellus were closer in Christology than in Trinitarian doctrine, nearly the reverse of the position more tentatively suggested by Parvis. ${ }^{99}$ Spoerl's second article explicates Eustathius's physiology in a particularly opaque fragment from the new epitome of Contra Ariomanitas $^{100}$. She argues that Eustathius has a broadly Aristotelian physiology and links the soul particularly with the heart. I myself have recently written three articles on Eustathius; the first examining the disembodied soul between death and resurrection, the second comparing his theology of the image of God with that found in Marcellus of Ancyra and Irenaeus, and the third examining the role of Christ's humanity within Eustathian Christology in light of Eustathius's explicit treatment of Platonism ${ }^{101}$.

This survey of Eustathius in modern research leaves us with a dappled picture: There has been detailed and on-going research into the events of Eustathius's life, (though the inevitable limitations of the available evidence must be acknowledged to be a substantial barrier to further advancement here); furthermore, Declerck's recent publication has brought our picture of Eustathius's corpus to a new level. However, with the exception of Eustathian exegesis, Eustathius's theology received very little attention between the early twentiethcentury and the last decade. For this reason, the framework for understanding Eustathius offered by scholars at the turn of the last century continues to be important in shaping discussion of him, and I now proceed to a discussion of it in order to elucidate the current state of research on Eustathius.

3. The contours of older research on Eustathius: an analysis. Four motifs were prominent in the treatment of Eustathius in late nineteenth and early twentieth-century scholarship: the first three were generally regarded as highly interrelated: firstly, Eustathius was seen as proto-Nestorian; secondly, as an adherent of the 'Asia Minor' tradition, dubbed 'Antiochene' by Loofs;

Dame, Indiana 2008, University of Notre Dame Press, 121-148; eadem, Eustathius of Antioch on Jesus' digestion, StPatr (2013) forthcoming.

${ }^{99}$ This comparison was taken up to elucidate Apollinarius's thought in K. Spoerl, Apollinarius and the First Nicene Generation, in: Tradition and the Rule of Faith in the Early Church: Essays in Honour of Joseph T. Lienhard, S.J., ed. by R. Rombs - A. Hwang, Washington DC 2010, Catholic University of America Press, 109-127. Spoerl argues that Apollinarius's Christology is anti-Eustathian, his Trinitarian theology anti-Marcellan.

${ }^{100}$ Cf. D4.

${ }^{101}$ Cf. S. Cartwright, The human soul between death and resurrection in Eustathius of Antioch, StPatr 52 (2011) 139-147; The image of God in Irenaeus, Marcellus and Eustathius, in: Irenaeus: life, scripture, legacy, ed. by P. Foster - S. Parvis, Augsburg 2012, Fortress Press, 173-181; Socalled Platonism, the soul and the humanity of Christ in Eustathius of Antioch's „Contra Ariomanitas et de anima", StPatr 66 (2013) 237-246. 
thirdly, as an Antiochene, literalist exegete. The first of these motifs provoked a strong negative reaction which nonetheless affirmed the category 'Nestorian' as a useful one for understanding Eustathius's divisive Christology. Fourthly, Eustathius was seen as a recalcitrant, and heroic, anti-Arian.

These interrelated conceptualisations of Eustathius were dependent on wider interpretative frameworks which have subsequently been either rejected or developed in new directions; pointedly, both earlier Germanic and earlier Anglophone scholarship had assumed the existence of two opposed traditions, 'Antiochene' and 'Alexandrian', by which wide-ranging issues in patristic theology could be understood. Germanic scholarship in particular had identified this Antiochene tradition with an 'Asia Minor' tradition, indebted to Irenaeus. These earlier conceptions of Eustathius also depended on particular confessional priorities which have since shifted. For example, Germanic scholarship at the turn of century had sought in 'Antiochene' or 'Asia Minor' theology a 'biblical' and 'historical', rather than 'philosophical' picture of Christ which had much to do with the contemporary reaction against a purportedly philosophising tendency in Christianity. Asia Minor and Antioch are held in sharp contradistinction to Alexandria with its Origenist and Platonic worldview.

Those who affirmed Eustathius's proto-Nestorian credentials saw his doctrine of Christ's human soul as part and parcel of his proto-Nestorianism, whilst those defending Eustathius against the charge of proto-Nestorianism, in particular Aloys Grillmeier, engaged with his doctrine of Christ's human soul only as part of his divisive Christology and hence regarded it as a defence against Arianism; it was something merely to explain away. Eustathius's unusual and highly interesting doctrine of Christ's human soul was generally, therefore, not considered in its own right. Friedrich Zoepfl is the notable exception to this rule, having posited a debt to Origen in Eustathius's doctrine of Christ's soul and, in the process, opening up some of the complexities of his treatment of it. Zoepfl's treatment, nonetheless, still starts from a straightforward contrast between Origen on one hand, and Asia Minor on the other, as influences on Eustathius.

Eustathius was consistently mentioned in discussions of the 'Arian' controversy prior to the publication of the newly-attributed epitome, but analysis of his anti-Arian theology was never very detailed.

4. The current state of Eustathian scholarship. Because of the comparative inattention to many aspects of Eustathius's thought in the latter half of the twentieth century, the work on Eustathius since the publication of the newlyattributed epitome has had the task of engaging with much earlier scholarship and has tended to make use, albeit critical use, of its categories. However, it has rejected the interpretative framework by which these categories were once held together within Eustathius's thought system. 
Beginning with the work of Michel Spanneut, the nature of Eustathian exegesis has been continually reassessed in line with developments in scholarship on the history of exegesis. This was partly because his one fully extant work, Engastrimytho, readily enables such a project. However, prior to the publication of the epitome of Contra Ariomanitas, there was no comparable reconsideration of Eustathius's Christology or his relationship to the theology of Irenaeus and Asia Minor, or the Antiochene tradition. The thus far limited scholarship on Eustathius since the publication of the epitome has begun to re-examine these categories. In the process of reassessing the role of divisive Christology and the Asia Minor tradition in Eustathius's theology, recent research has raised many new questions which have yet to be answered.

Recent scholarship has to some extent, and variously, affirmed the usefulness of the category 'Asia Minor' or 'Antiochene' as a contour for understanding Eustathius's theology. It has followed most closely Zoepfl's picture of Eustathius in this respect, seeing in Christ's human soul, among other things, an emphasis on Christ's full humanity. Navascués, understanding Eustathius as an 'Antiochene' theologian, takes this to denote a tradition distinct from Irenaeus. In focusing on Eustathius's Christology as a defining Antiochene feature, Navascués is in some ways closest to Loofs. However, insofar as he does not see Irenaeus as representative of Antiochene theology, he also owes much to the later work of Sellers and Grillmeier. Whereas, in the earlier, Germanic, scholarship, the 'Asia Minor' tradition had been connected with Nestorianism, more recent scholarship has either not made this connection, or has removed one of Asia Minor's purported champions in order to make it. Therefore, though often affirming both of them, it has not seen Eustathius's divisive Christology and Irenaeus's influence on him as indebted to a single tradition. This is a positive advance insofar as it acknowledges the complexity and eclecticism of Eustathius's outlook. However, the picture that more recent scholarship has eschewed did allow for a basically coherent, though problematic, account of Eustathian theology; jettisoning this account requires another one. More recent scholarship has only begun the task of seeking to understand how Eustathius's indebtedness to Irenaeus does, or does not, relate to his highly divisive Christology, and how both play out in the context of the 'Arian' controversy.

There have been valuable recent contributions to our picture of Eustathius's anti-Arian theology, particularly from Uthemann and Spoerl. Nonetheless, our incomplete understanding of Eustathius's theology inevitably means that our picture of his role in the 'Arian' controversy lacks sufficient detail. For instance, whilst Eustathius has recently been said to share with Marcellus of Ancyra - that other purported 'Asia Minor' theologian - an indebtedness to Irenaeus, a fierce anti-subordinatoinism, and a divisive Christology, not enough has been done to explain the relationship, or lack thereof, between these shared aspects of their thought. Uthemann has helped us to understand 
an important aspect of the relationship between divisive Christology and anti-subordinationism in Eustathius. A detailed and systematic consideration of the relationship between divisive Christology, any echoes of the doctrine of recapitulation, and anti-subordinationism in Eustathius's thought is now needed.

Even before Declerck's publication, Eustathius's engagement with Hellenic philosophy merited more in-depth consideration than it had received. This is because its treatment in older scholarship was patchy, and the subject was approached mainly via a consideration of his relationship to Origenism, which has itself been the subject of much recent re-evaluation ${ }^{102}$. Our new, clearer, understanding of Contra Ariomanitas offers an unprecedented opportunity for this reconsideration; the work of Spoerl and Navascués, and some of my work, begins to avail itself of this opportunity. Both Spoerl and Navascués argue persuasively that Aristotelianism was an important resource for Eustathius, and particularly for his anthropology. This suggests that the complex discourse about the role and prominence of Aristotle's thought in the third and fourth centuries must be an important one for the advance of our understanding of Eustathius ${ }^{103}$. However, largely because both of these contributions are in the form of relatively short articles, Eustathius's use of Aristotelian ideas has yet to be grounded in this discussion.

It is now necessary, then, both to re-examine the connections and tensions between different areas of Eustathius's thought and to consider the valuable recent insights on Aristotelianism in Eustathius in light of wider discourse on readings of Aristotle, including readings by Platonists, in the fourth century. The influence and counter-influence of Origen and Origenism on Eustathius must be fundamental to both of these enterprises: as both Zoepfl and, more recently, Uthemann, have suggested, we cannot fully understand Eustathius's doctrine of Christ's human soul without understanding his relationship to Origenism, but some recent work calls into question a comfortable dichotomy between Origenism and the Asia Minor tradition as influences shaping this doctrine. In particular, the relationship between Origen and has recently been reassessed as both more complex and more positive than was once thought ${ }^{104}$. Additionally, Mark Edwards' recent work on Origen suggests, among other things, that we need to allow a more complex picture of Aristotle's influence in antiquity to shape our understanding of Origen.

Eustathius's use of Aristotelian and Platonic ideas needs to be grounded in an understanding of the complex and dynamic relationship between the legacies Aristotle and Plato in the fourth century. This dynamic relationship, in

${ }^{102}$ Cf. M. Edwards, Origen Against Plato, Aldershot 2002, Ashgate.

${ }^{103}$ Recent examples include: L.P. Gerson, Aristotle and Other Platonists, London 2005, Cornell University Press; G. Karamanolis, Plato and Aristotle in agreement? Platonists on Aristotle from Antiochus to Porphyry, Oxford 2006, Clarendon Press.

${ }^{104}$ Cf. L.G. Patterson, Methodius of Olympus: divine sovereignty, human freedom and life in Christ, Washington DC 1997, Catholic University of America Press. 
turn, must be examined in connection with another, intra-Christian dynamic: that between Origenism and the 'Asia Minor' tradition. Eustathius's use of Hellenic philosophy does, as older scholars suggested, need to be understood in light of the history of Origenism and its critics. However, this history needs to be informed by a more dynamic picture of both Origen's supporters and his detractors, and the philosophy on which they drew.

Another highly important and potentially fruitful line of enquiry remains entirely unexplored: the more extensive scholarship on the events of Eustathius's later career has situated these events within the context of ecclesiastical politics, but has not comparably situated them within wider discussions about the relationship between the Church and the empire in the later years of Constantine's reign. The events of Eustathius's life from the time of his accession to Antioch could shed much light on the role of Nicaea in shaping this relationship.

For a long time, Eustathius did not receive the attention that his place in the Constantinian Church and his role in the early 'Arian' controversy should have merited. This was due in large part to the scarcity and fragmented nature of the sources, as is attested by the comparably greater attention paid to the components of his corpus. Declerck's magisterial achievement has brought the attempts to reconstruct Eustathius's corpus to an unprecedented level; the attribution to Eustathius of the epitomised Contra Ariomanitas et de anima provides a fresh opportunity to explore Eustathian theology. Subsequent scholarship on Eustathius has correspondingly made some important observations about his theological and philosophical outlook. However, it has yet sufficiently to ground these observations within current discourse on patristic theology and philosophy. Furthermore, in offering perspectives on Eustathius that partly break from, and partly reinvigorate, early understandings of him, more recent scholars have raised important new questions. Further scholarship is required.

\section{NOWE BADANIA NAD EUSTACJUSZEM Z ANTIOCHII}

\section{(Streszczenie)}

Eustacjuszowi z Antiochii ( $\dagger$ ok. 327), chociaż pełnił ważne funkcje w Kościele czasów Konstantyna Wielkiego i odegrał znaczną rolę na początku kontrowersji ariańskiej, nie poświęcano jednak należnej mu uwagi w badaniach naukowych. Najczęściej postrzegano go jako prekursora nestorianizmu i jako jednego z przedstawicieli egzegezy i teologii antiocheńskiej. Wynikało to w dużej mierze z niedoboru i fragmentaryczności źródeł. Inspiracją do podjęcia nowych badań nad Eustacjuszem stało się wydanie jego dzieł przez J.H. Declercka, a zwłaszcza zamieszczenie wśród nich Contra Ariomanitas et de anima (CCG 51, Turnhout 2002), streszczające jego poglądy teologiczne. W niniejszym artykule Autorka przedstawia pokrótce historię badań nad myślą Eustacjusza z Antiochii i dokonuje próby ich oceny. Wskazuje też równocześnie, w oparciu o najnowsze 
prace naukowe, na konieczność analizowania jego dzieł w odniesieniu do nauczania Orygenesa, jak również filozofii greckiej (platonizmu, arystotelizmu).

Słowa kluczowe: Eustacjusz z Antiochii, stan badań, Contra Ariomanitas. Key words: Eustathius of Antioch, state of research, Contra Ariomanitas. 